\title{
Agricultural activities
}

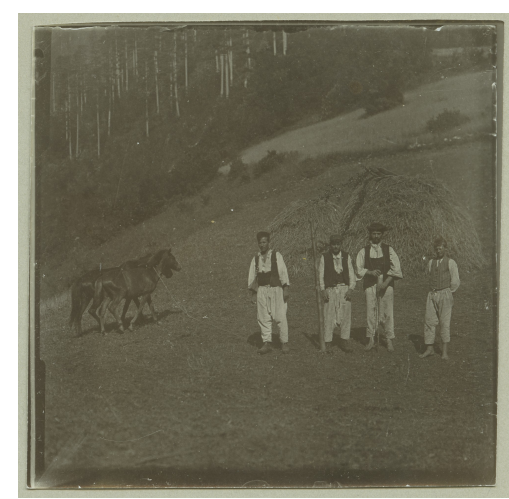

Agricultural activities

O The Austrian Museum of Folk Life and Folk Art

\begin{tabular}{|c|c|}
\hline Object: & Agricultural activities \\
\hline Description: & $\begin{array}{l}\text { Three men and a boy are standing in a } \\
\text { hayfield. Two horses are tied to a pole } \\
\text { with a long rope. In the background: a } \\
\text { haystack. }\end{array}$ \\
\hline Comment: & $\begin{array}{l}\text { Donated to the The Austrian Museum } \\
\text { of Folk Life and Folk Art by Dr. E. } \\
\text { Schneeweis. }\end{array}$ \\
\hline Date: & Not after 1915 \\
\hline Location: & Unknown \\
\hline Country: & Bosnia and Herzegovina \\
\hline Type: & Photograph \\
\hline Creator: & Schneeweis, Edmund, (Photographer) \\
\hline Dimensions: & Artefact: $89 \mathrm{~mm}$ x $89 \mathrm{~mm}$ \\
\hline Format: & Not specified \\
\hline Technique: & Not specified \\
\hline \multirow[t]{6}{*}{ Keywords: } & 290 Clothing \\
\hline & 130 Geography > 133 Topography and Geology \\
\hline & 230 Animal Husbandry $>231$ Domesticated Animals \\
\hline & 240 Agriculture \\
\hline & 460 Labor $>462$ Division of Labor by Gender \\
\hline & 890 Gender Roles and Issues \\
\hline Copyright: & Österreichisches Museum für Volkskunde \\
\hline Archive: & $\begin{array}{l}\text { The Austrian Museum of Folk Life and } \\
\text { Folk Art, Inv. No.: ÖMV/pos/3920 }\end{array}$ \\
\hline License: & $\begin{array}{l}\text { This picture is licensed under Creative } \\
\text { Commons [CC BY-NC-ND 3.0] (http:// } \\
\text { creativecommons.org/licenses/by-nc- } \\
\text { nd/3.0/) }\end{array}$ \\
\hline Editor: & Barbara Derler \\
\hline Permalink: & https://gams.uni-graz.at/o:vase.2690 \\
\hline
\end{tabular}

